\title{
Effects of urbanization on habitat characteristics: what are the responses of habitat alteration on functional feeding groups of aquatic invertebrates?
}

\author{
Jucimara Andreza Rigotti ${ }^{1 *}$ \\ Cesar Augusto Pompêo ${ }^{2}$ \\ Alessandra Larissa D'Oliveira Fonseca ${ }^{3}$ \\ ${ }^{1}$ Instituto de Pesquisas Hidráulicas, Universidade Federal do Rio Grande do Sul \\ Avenida Bento Gonçalves, 9.500, CEP 91.501-970, Porto Alegre - RS, Brasil \\ ${ }^{2}$ Departamento de Engenharia Sanitária e Ambiental \\ Universidade Federal de Santa Catarina \\ Campus Universitário, Trindade, CEP 88.040-970, Florianópolis - SC, Brasil \\ ${ }^{3}$ Coordenadoria Especial de Oceanografia, Universidade Federal de Santa Catarina \\ Campus Universitário, Trindade, CEP 88.040-970, Florianópolis - SC, Brasil \\ * Autor para correspondência \\ anrigotti@gmail.com
}

Submetido em 10/04/2019 Aceito para publicação 09/10/2019

\section{Resumo}

Efeitos da urbanização nas características do habitat: quais são as respostas dos grupos funcionais de alimentação dos invertebrados aquáticos à alteração do habitat? A urbanização causa muitas alterações nas comunidades aquáticas. Sob ocupação urbana intensa, os rios sofrem as maiores modificações estruturais. O objetivo do trabalho foi avaliar os efeitos da urbanização nas características físicas e químicas do habitat e as respostas da urbanização nos grupos funcionais de alimentação (FFG) dos invertebrados. Parâmetros de qualidade da água (temperatura, condutividade, oxigênio dissolvido, $\mathrm{pH}$, fósforo, clorofila-a, turbidez e matéria orgânica) e parâmetros do escoamento foram medidos em áreas pouco e altamente urbanizadas. Os FFG dos macroinvertebrados foram analisados e aplicados como substitutos de atributos do ecossistema. As diferenças na comunidade dos macroinvertebrados entre as áreas pouco e altamente urbanizadas foram avaliadas pelo escalonamento multidimensional não-métrico (nMDS) e pela análise de variância permutacional multivariada (Permanova). No nMDS foram observadas diferenças entre as áreas pouco e altamente urbanizadas. A Permanova mostrou diferença significativa entre os grupos do nMDS. As áreas pouco urbanizadas apresentaram maior riqueza em cada FFG, por outro lado, as áreas altamente urbanizadas apresentaram maiores valores de abundância de organismos coletores e predadores. Assim, a composição dos FFG respondeu às alterações no habitat que foram representadas pelos parâmetros de qualidade da água e do escoamento.

Palavras-chave: Atributos do ecossistema; Macroinvertebrados; Qualidade da água; Rios urbanos

\section{Abstract}

Urbanization causes many changes in stream communities and rivers usually suffer major structural modifications under intense urban occupation. The goal of this study was to investigate the effects of urbanization 
on physicochemical habitat characteristics and evaluate the responses of urbanization on functional feeding groups (FFGs) of invertebrates. Water quality parameters (temperature, conductivity, dissolved oxygen, $\mathrm{pH}$, phosphorus, chlorophyll-a, turbidity and organic matter) and flow parameters were measured in least and severely urbanized areas. FFGs of macroinvertebrates were analyzed and applied as surrogates of ecosystem attributes. The differences in the macroinvertebrate community of the least and severely urbanized areas were assessed using non-metric multidimensional scaling (nMDS) and a permutational multivariate analysis of variance (Permanova). Differences between the least and severely urbanized areas were observed with nMDS. The Permanova also showed a significant difference between the nMDS groups. The least urbanized areas presented greater richness for each FFG. On the other hand, severely urbanized areas presented a major abundance of gathering collectors and predators. Thus, the composition of FFGs responded to habitat alterations that were represented by water quality and the flow parameters.

Key words: Ecosystem attributes; Macroinvertebrates; Urban rivers; Water quality

\section{Introduction}

Regulation of rivers has profoundly altered water regimes and habitat dynamics, modifying conditions for aquatic and terrestrial wildlife (ARLETTAZ et al., 2011). Physical habitat alteration is the most significant threat to biodiversity and ecosystem function in the majority of human-impacted river systems (ALLAN; CASTILLO, 2007). The most intensive effects are observed in urban areas, where urbanization causes many alterations in stream communities (PAUL; MEYER, 2001). Watercourses usually suffer major structural modifications under an intense condition of urbanization and these changes considerably reduce invertebrate diversity (BAZINET et al., 2010; HOGGART et al., 2012).

The lower persistence of macroinvertebrate assemblages in the channelized section of a stream might be attributable to the lower availability of refuges, since channelization tends to constrain stream channels and impedes the development of complex lateral habitats (NEGISHI et al., 2002). In addition, the alteration stages involving channelization, dredging or incision that concentrate flows within the channel to accentuate flood peaks may damage or wash out physical habitat features and diminish floodplain interactions (CLUER; THORNE, 2014). Channelization and bank stabilization are factors of habitat simplification, resulting in one of the most common causes of fluvial connectivity loss (WARD, 1998). However, the effects of channelization on macroinvertebrate communities and the degree of recovery are poorly studied and deserve more attention under different conditions (KÄIRO et al., 2017).

The habitat alterations caused by channelization can be expressed through hydraulic indices that characterize flow patterns. Manning's coefficient represents channel roughness (CHOW, 1959) and is widely applied on hydraulic engineering. Froude and Reynolds numbers are dimensionless hydraulic parameters that characterize flow regime (DINGMAN, 2009). Studies have linked flow regime to biological responses (DAVIS; BARMUTA, 1989; THOMSON et al., 2004; BROOKS et al., 2005; MESA, 2010). In this regard, high diversity is sustained in stream invertebrate communities due to an interaction between low levels of disturbance and habitat patchiness (DEATH; WINTERBOURN, 1995). Thus, benthic macroinvertebrates are largely applied as predictors of habitat condition related to the range of flow velocity, water depth and substrate type (BROOKS; HAEUSLER, 2016; THEODOROPOULOS et al., 2017).

Linking habitat alterations to community composition can also be done using a functional approach based on traits of the invertebrate community. Yoshimura et al. (2006) applied abundance data and ratios of FFGs as proxy indicators to assess river ecosystem attributes. A function-based assessment is more directly related to ecosystem processes than solely to taxonomic composition (YOSHIMURA et al., 2006). Organism traits are related to variations in environmental conditions (JOVEM-AZEVÊDO et al., 2019) and to human disturbance that lead to a less 
functionally diverse community (FEIO et al., 2015). Feeding group is a functional characteristic that is based on morphological and behavioral characteristics of invertebrates related to the manner they acquire their food resources (CUMMINS, 2016). The functional feeding groups (FFGs) methodology could be used as a surrogate for direct measures of important ecosystem attributes, providing critical data with much less effort (MERRITT et al., 2002). The use of relationships among FFGs provides useful information about ecosystem stability, energy flow and trophic webs (MERRITT et al., 2017).

In the light of the above, the purpose of this study was to investigate the effects of urbanization on physicochemical habitat characteristics and evaluate the responses of urbanization on FFGs of invertebrates.

\section{Materials and Methods}

\section{Study area and sampling design}

The study area is located on Santa Catarina Island, in the South Region of Brazil. The Itacorubi hydrographic basin is in the central part of the island and has a $27.7 \mathrm{~km}^{2}$ drainage area. About $30 \%$ of Santa Catarina Island comprises legal environmental protection areas, including coastal dunes, mangroves and remnants of Atlantic Forest vegetation on hillsides. However, the connection between the forest fragments and mangrove is decreasing because of urban occupation.

Two main rivers of the Itacorubi hydrographic basin were selected according to river length and drainage area (Figure 1). The streams flow into the

FIGURE 1: Itacorubi hydrographic basin and natural conservation areas under the basin limits. Sampling sites are in catchment areas where the impervious surface cover was estimated. C - Córrego Grande River; M - Rio do Meio River; 1 - least urbanized area; 2 - severely urbanized area.

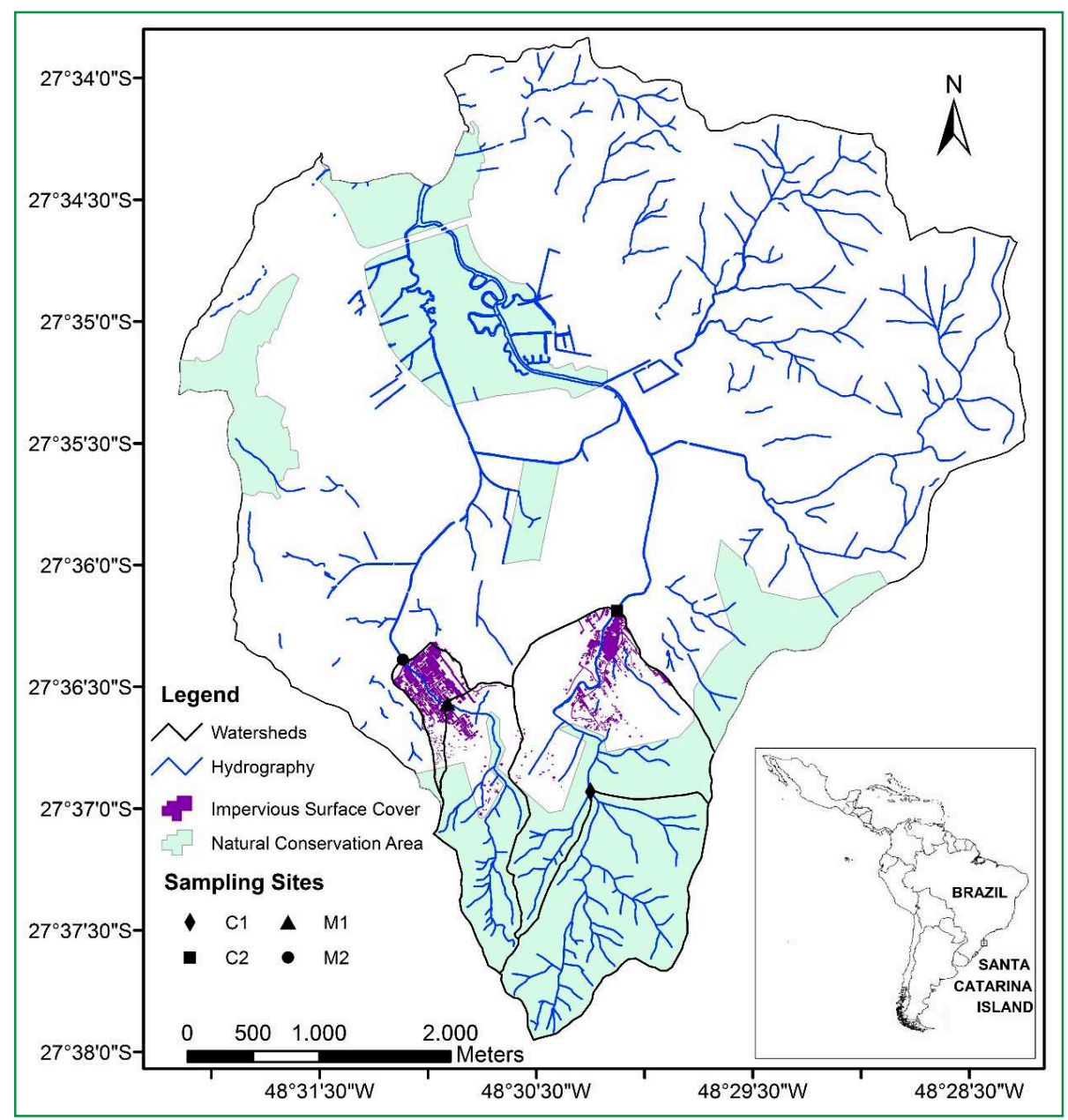


mangrove area from forested headwaters; both start in a natural conservation area and drain into the mangrove forest natural reserve. Córrego Grande River (C) is not channeled along its entire length; in other words, there is no concrete covering on the river bed over $8.6 \mathrm{~km}$, even in the urban area. This river has a project of river greenway approved by municipal law. On the other hand, Rio do Meio River (M) is channeled with bed cover changes on $1.0 \mathrm{~km}$ of $7.2 \mathrm{~km}$ of the total length. The channelization was made around 1960 due to the installation of the Federal University of Santa Catarina campus. In 2013 the university started an institutional project to improve the water quality of rivers that flow through the campus area.

Sampling sites were selected according to urban condition: $\mathrm{C} 1$ and $\mathrm{M} 1$ are in the least urbanized areas and $\mathrm{C} 2$ and $\mathrm{M} 2$ are in severely urbanized areas. Impervious surface cover was quantified by manual vectorization (MicroStation software). The estimation was performed with aerial photographs and a topographical survey. In addition, supplementary observation of drainage network design was performed in situ. The index of imperviousness was estimated for each catchment using the total impervious area that is directly connected in watercourses through the drainage network. $\mathrm{C} 1$ and M1 are in headwater areas that are relatively well preserved, and these areas have no drainage pipes directly connected in the watercourses. Although M1 has an urbanized area inside the catchment, the runoff from the imperviousness of this area is not connected to the watercourse upstream of the sampling site. The $\mathrm{C} 2$ and $\mathrm{M} 2$ sites were selected in the downstream part of the rivers. Both downstream sites are located in severely urbanized areas; $\mathrm{C} 2$ has 3.4\% and $\mathrm{M} 2$ has $10.6 \%$ impervious surface cover. $\mathrm{C} 2$ and $\mathrm{M} 2$ have a drainage network and sanitary sewerage systems, whereas M2 is channelized with a concrete covering.

Data collection was performed monthly from February to April 2014. The maximum air temperature ranged from 21.6 to $32.4^{\circ} \mathrm{C}$ on the days of fieldwork (EPAGRI, 2014). The monthly precipitation in the summer of 2014 was below the normal average for the same period on Santa Catarina Island. The normal average was $195.2 \mathrm{~mm}$ in February, $158.1 \mathrm{~mm}$ in March, and $113.0 \mathrm{~mm}$ in April (data from 1981 to 2010 -
EPAGRI, 2014). In 2014, the monthly precipitation was $155.1 \mathrm{~mm}, 104.8 \mathrm{~mm}$ and $116.5 \mathrm{~mm}$ in February, March, and April, respectively (EPAGRI, 2014). In addition, the previous precipitation value was less than $10 \mathrm{~mm}$ during the five days preceding the fieldwork, and there was no precipitation on the days of data collection.

\section{Physicochemical parameters}

Water temperature, conductivity (model YSI-EC 300), dissolved oxygen (model YSI - 55), and $\mathrm{pH}$ (model YSI - 100 AC) were measured in situ at each sampling site. Two samples of water with a volume of one liter were also collected for analysis of dissolved inorganic phosphorus, chlorophyll-a, and turbidity. The samples were taken and preserved according to standardized procedures. In the laboratory, soon after field data collection, the turbidity was measured (AlfaKit turbidimeter) and the remaining samples were immediately filtered and frozen. Phosphorus analysis was performed using the colorimetric method, according to Grasshoff et al. (1983). Chlorophyll-a was extracted using the Nusch (1980) method and the absorbance was read with a spectrophotometer (HITACHI - U2900) and determined by Lorenzen's equations (LORENZEN, 1967). Parameters that were measured in the field, with a multiparameter probe, had five measurements per collection; since we did three collections, $n=15$ for each sampling site. Since parameters that were quantified in the laboratory (dissolved inorganic phosphorus, chlorophyll-a, turbidity and organic matter) had 2 replicas per collection, $\mathrm{n}=6$ for each sampling site.

Substrates retained by a sampler net, comprising vegetation, detritus and some sediments, were also analyzed after fauna screening. The samples were dried at $60^{\circ} \mathrm{C}$ to a constant weight and subsampled. Organic matter was determined by the calcination method (under $550^{\circ} \mathrm{C}$ for two hours) using a quarter of each dried sample.

\section{Flow parameters}

In the field, water velocity and depth were measured. Mean water velocity was measured by the float method due to the streamflow characteristics of 
turbulence and low depth. We applied the method to distances from 1 to $10 \mathrm{~m}$, and repeated the procedure several times, using two floater sizes $(5$ and $2.5 \mathrm{~cm}$ diameter). Section data were also collected to calculate the transversal area of sampling sites. Stream slope was estimated by a topographic survey with a detailed scale map (1:2000). The flow parameters measured in the field were used to estimate hydraulic parameters (Manning's coefficient, Froude and Reynolds numbers).

The energy loss, usually understood in a general sense as roughness, was expressed in terms of Manning's coefficient. The coefficient was calculated by Manning's equation (DINGMAN, 2009):

$$
U=\frac{1}{n} \cdot R_{h}^{\frac{2}{3}} \cdot S^{\frac{1}{2}}
$$

; where $U$ is mean velocity; $n$ is Manning's coefficient; $R_{h}$ is hydraulic radius ( $R_{h}$ is defined by the ratio between wetted area and wetted perimeter of the transversal section); and $S$ is slope.

The Froude number $(F r)$ represents the relation between inertial and gravitational forces, and flow is classified as critical $(F r=1)$, supercritical $(F r>1)$ and subcritical $(F r<1)$. It is calculated by:

$$
F r=\frac{U}{\sqrt{g \cdot D}}
$$

; where, $\mathrm{U}$ is mean velocity; $\mathrm{g}$ is gravity acceleration; and $\mathrm{D}$ is water depth.

The Reynolds number $(R e)$ represents the relation between inertial and viscous forces. It is a turbulence measurement of the flow. According to the Reynolds number, the flow regime is laminar or turbulent. When $R e<500$, disturbances to the flow are damped out by viscous friction. When $R e>2,000$, the inertia of water particles is sufficient to overcome the viscous damping, representing a turbulent regime (DINGMAN, 2009). Transitional flow occurs when $500<R e<2,000$. The Reynolds number is calculated by:

$$
R e=\frac{U \cdot R h}{v}
$$

; where $U$ is mean velocity; $R h$ is hydraulic radius; and $v$ is kinematic viscosity.

Manning's coefficient is applied as an approximation of roughness and turbulence. The classification of laminar and turbulent regimes, provided by Reynolds number, might not be helpful for rivers, where the flow is essentially turbulent. The laminar flow is so rare on watercourses that the classification is relevant only as a theoretical framework (ALAN; CASTILLO, 2007). However, Reynolds and Froude numbers are the most common hydraulic indices used in fluvial ecology (THOMSON et al., 2004; BROOKS et al., 2005).

\section{Macroinvertebrate sampling}

Macroinvertebrate sampling was performed at each site - two samples per site during three field data collections - using a Surber sampler (mesh size 500 $\mu \mathrm{m}$, sampler area $900 \mathrm{~cm}^{2}$ ). The samples were collected in different hydraulic microhabitats (riffles and pools) and different substrate types along the stream segment. The predominant substrate of the watercourses is composed of coarse gravel. However, the channelized site is composed of concrete, with some blocks and filamentous algae that grow on concrete cover. The samples were packed and preserved in $70 \%$ ethanol. In the laboratory, all samples were examined under a stereoscopic microscope. Organisms were identified using available taxonomic keys, especially Merritt and Cummins (1996), Cummins et al. (2005), Froehlich (2007) and Mugnai et al. (2010).

\section{Functional Feeding Groups (FFGs)}

Taxonomic identification was as specific as possible when assigning functional feeding groups (FFGs) according to Cummins et al. (2005), which assess the FFGs based on morphological characteristics and behavioral mechanisms. The organisms were separated into five classes: shredders, scrapers, filtering collectors, gathering collectors and predators (CUMMINS et al., 2005). Invertebrates that fragmented conditioned 
litter or live vascular plants (material denominated coarse particulate organic matter - CPOM) are shredders. Scrapers remove attached biofilm from surfaces. Collectors feed on fine particulate organic matter (FPOM). They are subdivided into: a) filtering collectors that filter FPOM from the water column, using constructed silken nets or filtering fans; and b) gathering collectors that acquire FPOM from interstices in the bottom sediments. Predators are defined as those invertebrates that capture and consume live prey. The results were also compared with Ramírez and GutiérrezFonseca (2014) that identified some variation in the use of the FFG classification, in part due to an emphasis on analyzing gut content.

According to Cummins et al. (2005), FFGs can be used as an indirect measure of ecosystem attributes. The ecosystem attributes evaluated using this methodology are: gross primary production as a proportion of community respiration $(\mathrm{P} / \mathrm{R}), \mathrm{CPOM}$ as a proportion of
FPOM (CPOM/FPOM), suspended particulate organic matter as a proportion of deposited (benthic) particulate organic matter (SPOM/BPOM), availability of stable surfaces and non-shifting sediments (habitat stability), and top-down control of predators on prey (top-down control). Reference values of FFG ratios were adopted according to Merritt et al. (2002) and Cummins et al. (2005), which are reproduced on Table 1. Feeding trophic groups are associated with organic material available for species; this analysis allows the trophic dynamics in ecosystems to be inferred (JOVEM-AZEVÊDO et al., 2019). Any change in ecosystem condition that impacts the nutritional resource base of the invertebrates will be captured by measurements of the relative proportions of FFGs and therefore important ecosystem attributes can be evaluated using these FFG ratios (CUMMINS et al., 2005). Physical habitat forms a part of the ecosystem condition; accordingly, ecosystem attributes based on FFGs also allow the assessment of the physical condition of a river habitat for invertebrates.

TABLE 1: Functional feeding groups (FFGs) relationships and ecosystem attributes, description, ratios and general criteria (MERRITT et al., 2002; CUMMINS et al., 2005).

\begin{tabular}{|c|c|c|c|c|}
\hline Ecosystem attributes & $\begin{array}{l}\text { Symbols for } \\
\text { ecosystem } \\
\text { attributes }\end{array}$ & $\begin{array}{l}\text { Ecosystem attribute } \\
\text { description }\end{array}$ & $\begin{array}{l}\text { Functional feeding } \\
\text { group ratios for } \\
\text { attributes }\end{array}$ & $\begin{array}{c}\text { General criteria ratio } \\
\text { levels }\end{array}$ \\
\hline $\begin{array}{l}\text { Autotrophy to } \\
\text { heterotrophy index }\end{array}$ & $\mathrm{P} / \mathrm{R}$ & $\begin{array}{l}\text { Gross primary } \\
\text { production as } \\
\text { a proportion of } \\
\text { community } \\
\text { respiration }\end{array}$ & $\begin{array}{l}\text { Shredders }+ \text { scrapers as } \\
\text { a proportion } \\
\text { of shredders }+ \text { gathering } \\
\text { collectors }\end{array}$ & $\begin{array}{l}\text { Autotrophic system: } \mathrm{P} / \mathrm{R} \\
=>0.75\end{array}$ \\
\hline $\begin{array}{l}\text { Coarse particulate organic } \\
\text { matter (CPOM) to fine } \\
\text { particulate organic matter } \\
\text { (FPOM) index }\end{array}$ & CPOM/FPOM & $\begin{array}{l}\text { Coarse particulate } \\
\text { organic matter as a } \\
\text { proportion of fine } \\
\text { particulate organic } \\
\text { matter }\end{array}$ & $\begin{array}{l}\text { Shredders as a } \\
\text { proportion of collectors }\end{array}$ & $\begin{array}{l}\text { Normal shredder riparian } \\
\text { system by season } \\
\text { (spring-summer): } \\
\text { CPOM/FPOM }=>0.25\end{array}$ \\
\hline $\begin{array}{l}\text { FPOM in transport } \\
\text { (suspended) to FPOM } \\
\text { storage in sediments } \\
\text { (deposited in benthos) }\end{array}$ & SPOM/BPOM & $\begin{array}{l}\text { Suspended particulate } \\
\text { organic matter as a } \\
\text { proportion of deposited } \\
\text { (benthic) particulate } \\
\text { organic matter }\end{array}$ & $\begin{array}{l}\text { Filtering collectors as a } \\
\text { proportion of gathering } \\
\text { collectors }\end{array}$ & $\begin{array}{l}\text { Enriched in SPOM: } \\
\text { SPOM/ BPOM }=>0.50\end{array}$ \\
\hline $\begin{array}{l}\text { Substrate (channel) } \\
\text { stability }\end{array}$ & $\begin{array}{l}\text { Habitat } \\
\text { Stability }\end{array}$ & $\begin{array}{l}\text { Availability of stable } \\
\text { surfaces and non- } \\
\text { shifting sediments }\end{array}$ & $\begin{array}{l}\text { Scrapers }+ \text { filtering } \\
\text { collectors as a } \\
\text { proportion of shredders } \\
+ \text { gathering collectors }\end{array}$ & $\begin{array}{l}\text { Stable substrates not } \\
\text { limiting in rivers: Habitat } \\
\text { Stability }=>0.50\end{array}$ \\
\hline Top-down control & $\begin{array}{l}\text { Top-Down } \\
\text { Control }\end{array}$ & $\begin{array}{l}\text { Top-down control of } \\
\text { predators on prey }\end{array}$ & $\begin{array}{l}\text { Predators as a } \\
\text { proportion of total of all } \\
\text { other functional feeding } \\
\text { groups }\end{array}$ & $\begin{array}{l}\text { Normal top-down } \\
\text { predator control: top- } \\
\text { down control }<=0.15\end{array}$ \\
\hline
\end{tabular}




\section{Data analysis}

Urbanization effects on physicochemical parameters were evaluated by descriptive statistic methods, using the R statistical software. The physicochemical graphics illustrate the differences between least urbanized areas (C1 and M1) and severely urbanized areas (C2 and M2). The responses of the invertebrates to the urbanization condition were evaluated through the discussion of differences found for the ecosystem attributes of FFGs and the composition of macroinvertebrates in each FFG. FFG ratios as surrogates to ecosystem attributes were estimated (as described in the section above) and the results were plotted as ecosystem attribute graphics with the reference values. In addition, the abundance (number of organisms of each taxon) and richness (number of taxa) related to each FFG were presented. Non-metric multidimensional scaling (nMDS) and a one factor permutational multivariate analysis of variance based on distances (Permanova) were also applied to confirm the differences between the urbanization conditions. These analyses were performed with software Primer 6, with 999 permutations for the Permanova (ANDERSON et al., 2008; ANDERSON, 2017). The similarity matrix (Bray-Curtis) was created with transformed (square root) data of macroinvertebrate abundance.

\section{Results}

\section{Physicochemical parameters}

Physicochemical parameters present variations according to the least urbanized areas (C1 and M1) and severely urbanized areas (C2 and M2). Least urbanized areas showed the lowest values of phosphorus in relation to severely urbanized areas. Phosphorus values were above the legal limit ( $0.1 \mathrm{mg} . \mathrm{L}^{-1}$ of total phosphorus) in severely urbanized areas (Figure $2 \mathrm{H}$ ). These results offer compelling evidence of clandestine domestic effluent disposal without treatment in streams. Interestingly, the DO graph of M2 (Figure 2A) was not so low, as expected according to the phosphorus concentration. The average scores were higher in the channelized site (M2), mainly due to conductivity, turbidity, and chlorophyll (Figures 2D, E, G).

\section{Stream flow}

Stream flow parameters were in accord with hydrologic characteristics of the catchments related to the small area and urban surface imperviousness. Velocity and water depth (Table 2) match with the low precipitation that occurred before sampling. Manning's coefficient had different values for M2 (the channeled site). The Froude number indicated subcritical flow, and the Reynolds number showed a turbulent regime.

TABLE 2: Stream flow characterization results

\begin{tabular}{cccccc}
\hline $\begin{array}{c}\text { Sampling } \\
\text { sites }\end{array}$ & Water depth*(m) & Velocity* $\left(\mathbf{m . s}^{-\mathbf{1}}\right)$ & $\begin{array}{c}\text { Manning's } \\
\text { coefficient** }\end{array}$ & Froude number** & $\begin{array}{c}\text { Reynolds } \\
\text { number*** }\end{array}$ \\
\hline C1 & 0.17 & $0.20 \pm 0.02$ & 0.160 & 0.15 & 20,164 \\
M1 & 0.11 & $0.13 \pm 0.03$ & 0.356 & 0.14 & 8,509 \\
C2 & 0.13 & $0.48 \pm 0.12$ & 0.114 & 0.43 & 39,759 \\
M2 & 0.05 & $0.35 \pm 0.06$ & 0.041 & 0.56 & 7,698 \\
\hline
\end{tabular}

*Water depth (in the middle of the section) and velocity measured in the field ( \pm standard error). **Manning's coefficient, Froude and Reynolds numbers were estimated from field data. C - Córrego Grande; M - Rio do Meio; 1 - least urbanized area; 2 - severely urbanized area. 
FIGURE 2: Physicochemical parameters, median, first, and third quartiles, minimum and maximum. A. dissolved oxygen saturation (DO \%), B. water temperature $\left({ }^{\circ} \mathrm{C}\right), \mathrm{C} . \mathrm{pH}, \mathrm{D}$. conductivity $(\mu \mathrm{S})$, E. turbidity $(\mathrm{NTU})$, F. organic matter (\%), G. chlorophyll-a ( $\mu$ g.L$\left.{ }^{1}\right)$, H. phosphorus (mg.L-1 $)$. C - Córrego Grande; M - Rio do Meio; 1 - least urbanized area; 2 - severely urbanized area.

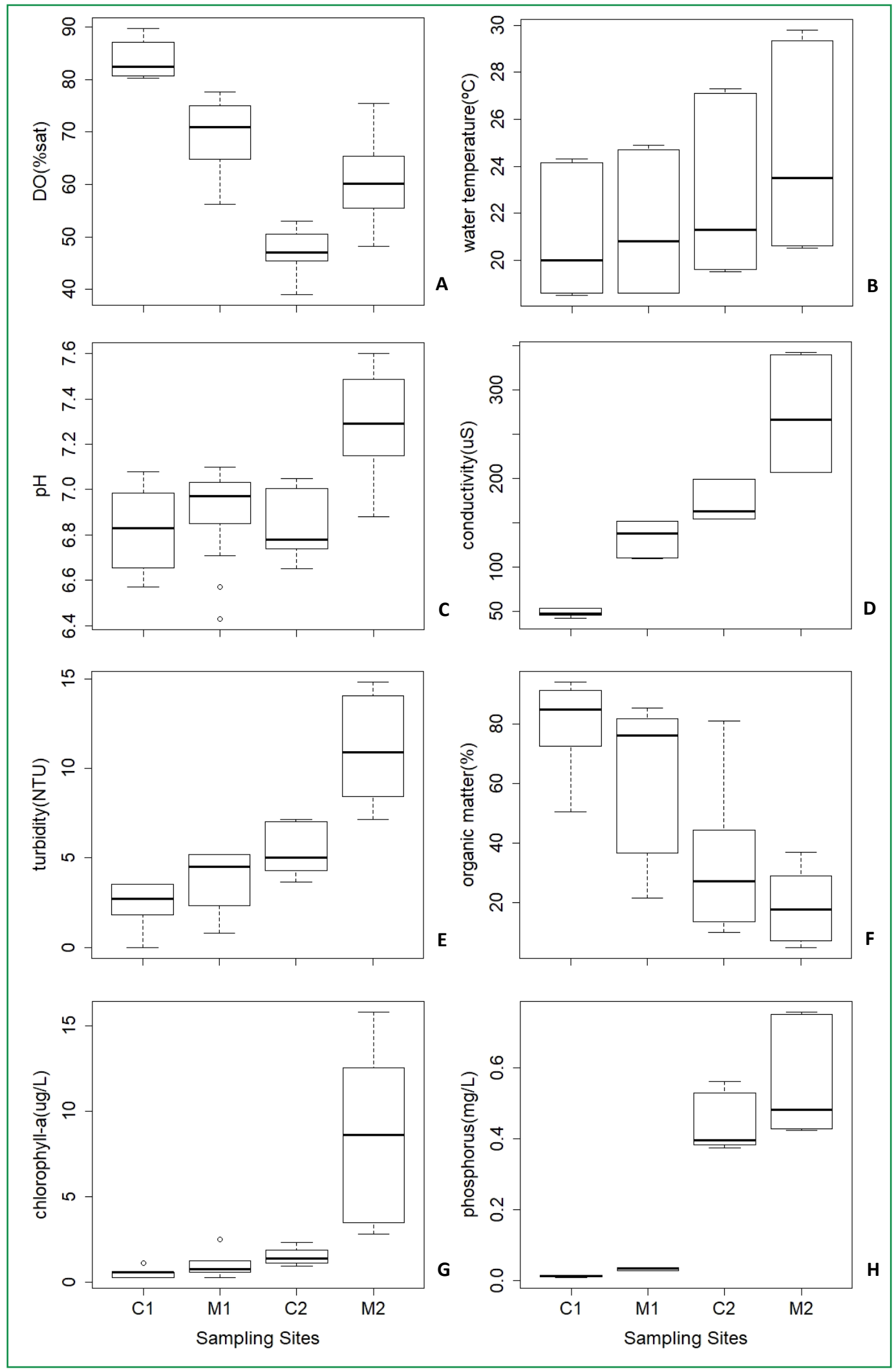


Functional feeding groups of macroinvertebrate community

There was a separation between least urbanized areas and severely urbanized areas, according to macroinvertebrate data (Figure 3). The Permanova confirmed the nMDS result. There was a significant difference between the nMDS groups (Pseudo$F=13.501$, d.f. $=2, P=0.003$ ).
In general, least urbanized areas present greater taxonomic richness in each FFG than severely urbanized ones, except for gathering collectors of Córrego Grande River (Table 4). On the other hand, abundance in severely urbanized areas (C2 and M2) has higher values. What stands out in the results is a lack of shredders and the high abundance of gathering collectors (mainly Chironomidae and Oligochaeta) in C2 and M2.

FIGURE 3: nMDS result for the macroinvertebrate abundance data. C - Córrego Grande; $\mathrm{M}$ - Rio do Meio; 1 - least urbanized area; 2 severely urbanized area.

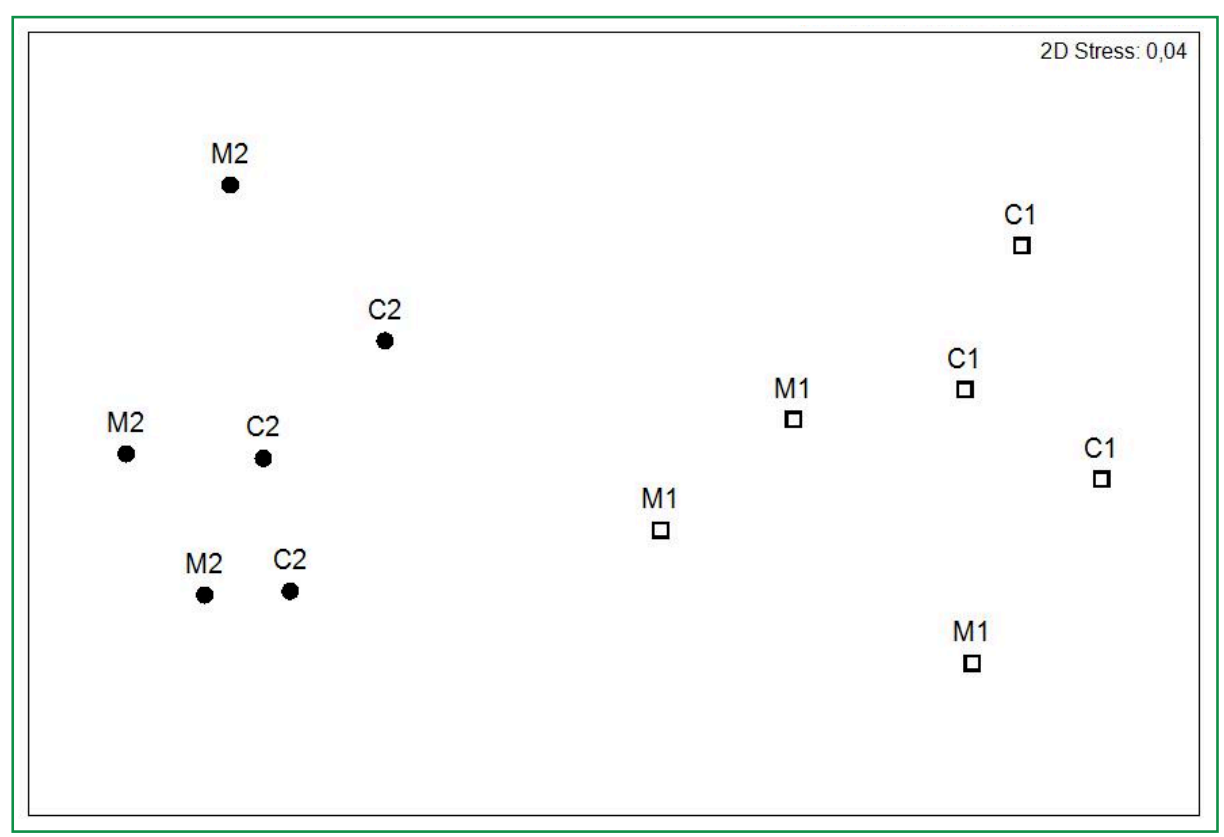

TABLE 4: Abundance of organisms in each functional feeding group (FFG) and sampling site.

\begin{tabular}{lcccc}
\hline \multirow{2}{*}{ FFG } & \multicolumn{3}{c}{ Sampling sites } & M2 \\
\cline { 2 - 5 } Shredders & M1 & & & \\
Decapoda & 11 & 3 & & \\
Gripopterygidae & 5 & 12 & & \\
Calamoceratidae & 4 & 6 & & 5581 \\
Gathering collectors & & & 6470 & 1125 \\
Chironomidae & 245 & 548 & 525 & 3 \\
Oligochaeta & 6 & 49 & 3 & \\
Leptophlebiidae & 52 & 26 & 1 & 1 \\
Elmidae-l & 48 & 30 & 5 & \\
Caenidae & 45 & 2 & & \\
Baetidae & 7 & &
\end{tabular}




\begin{tabular}{|c|c|c|c|c|}
\hline Ceratopogonidae & 3 & 13 & 11 & \\
\hline Nemertea & & 27 & 91 & 7 \\
\hline Collembola & & 14 & 2 & \\
\hline Stratyiomidae & & & 1 & \\
\hline \multicolumn{5}{|l|}{ Predators } \\
\hline Odonata & 44 & 52 & 14 & 4 \\
\hline Perlidae & 22 & 9 & 1 & \\
\hline Gerromorpha & 19 & 4 & 1 & \\
\hline Empididae & 4 & 4 & 29 & 4 \\
\hline Acari & 3 & & & \\
\hline Hydrobiosidae & 1 & & & \\
\hline Tipulidae & 1 & & & \\
\hline Hirudinea & & & 414 & 1081 \\
\hline Staphilinidae & & 1 & & \\
\hline Hydrozoa & & & & 19 \\
\hline \multicolumn{5}{|l|}{ Filtering collectors } \\
\hline Hydropsychidae & 13 & 31 & & \\
\hline Leptoceridae & 4 & & & \\
\hline Polycentropodidae & 2 & 1 & & \\
\hline Bivalvia & 1 & 1 & & \\
\hline Simuliidae & & 1 & 82 & 1 \\
\hline \multicolumn{5}{|l|}{ Scrapers } \\
\hline Gastropoda & 20 & 325 & 99 & 104 \\
\hline Psephenidae & 20 & 5 & & \\
\hline Elmidae- $a$ & 14 & 18 & & \\
\hline Glossosomatidae & 9 & & & \\
\hline Hydroptilidae & 6 & 9 & 2 & \\
\hline Pyralidae & 1 & & 1 & \\
\hline Odontoceridae & 1 & & & \\
\hline
\end{tabular}

According to ecosystem attributes estimated through FFGs of macroinvertebrates, all sites are heterotrophic in relation to $\mathrm{P} / \mathrm{R}<0.75$ (Figure $4 \mathrm{~A}$ ). The $\mathrm{CPOM}$ to FPOM ratio indicated that shredders were not abundant (Figure 4B). Also, FPOM is in the benthic compartment instead of suspended in the water column (Figure 4C). 
FIGURE 4: Ratios of FFGs of macroinvertebrates related to ecosystem attributes and reference value. C - Córrego Grande; M - Rio do Meio; 1 - least urbanized area; 2 - severely urbanized area. P/R - Gross primary production as a proportion of community respiration; CPOM/FPOM - Coarse particulate organic matter as a proportion of fine particulate organic matter; SPOM/ BPOM - Suspended particulate organic matter as a proportion of deposited benthic particulate organic matter; Habitat stability - Availability of stable surfaces and non-shifting sediments; TOP-DOWN control - Top-down control of predators on prey.

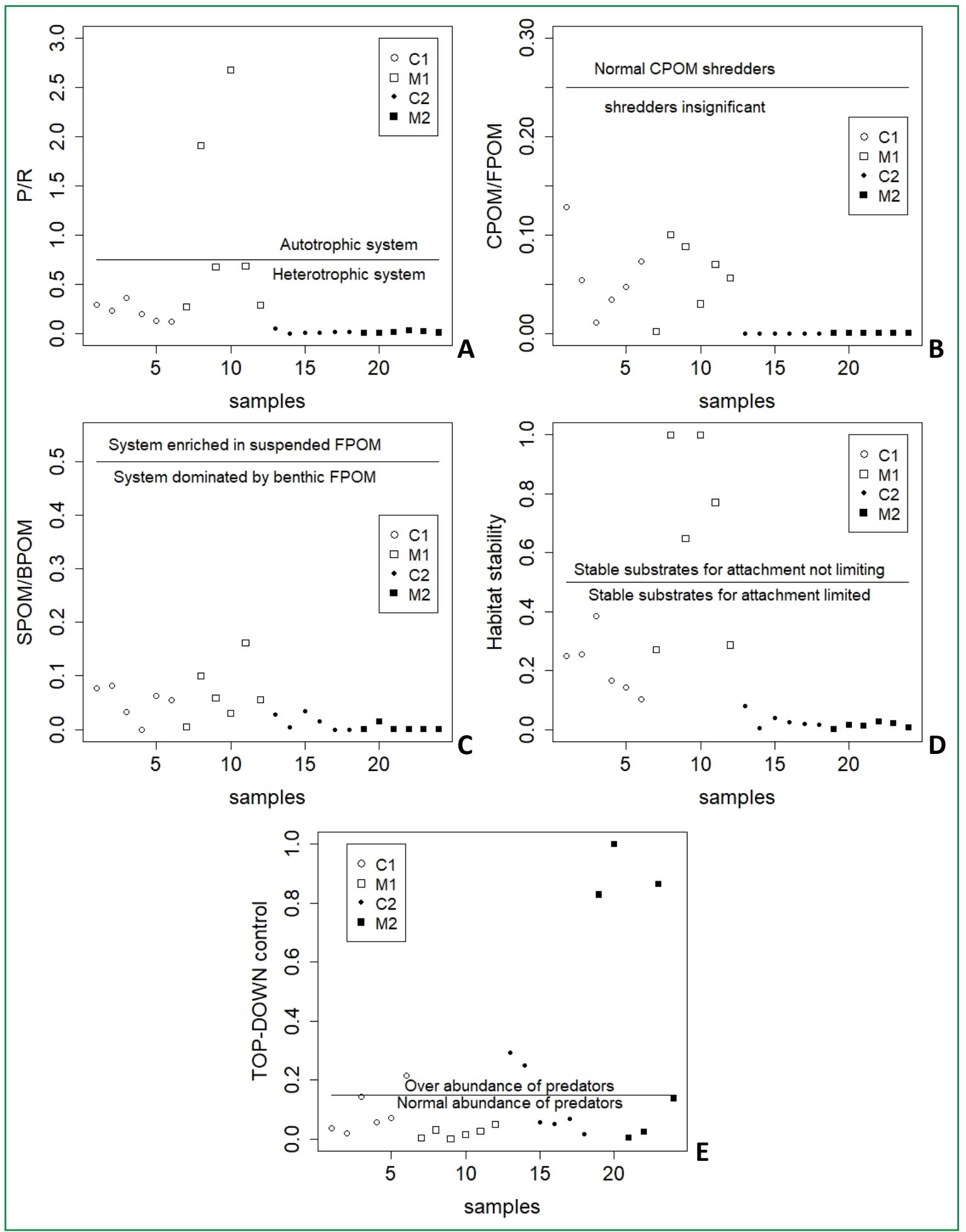




\section{Discussion}

Urban occupation with no adequate domestic sewage treatment and high impervious surface cover were drivers of the results of physicochemical parameters, benthic habitat, and FFG composition. The difference between least urbanized areas and severely urbanized areas was observed in the nMDS and Permanova results. Phosphorus results also confirm the visual observations of direct effluent pipe connections in watercourses that were registered, but not quantified, during field surveys. The phosphorus value is an important indicator, since nutrient dynamics play a role in fluvial processes (MULHOLLAND; WEBSTER, 2010). The control of the inflow of nutrients into the rivers is thus noticed as a relevant action to water quality enhancement (VISWANATHAN; SCHIRMER, 2015). Urban areas with high impervious surface cover and direct connection with stormwater drainage have been identified as causes of severe degradation of stream ecosystems (WALSH et al., 2005; 2012). Although drainage systems are separate from sewage systems in Brazil, it is very common to find connected sewage in drainage systems. The major pollution load that reaches urban watercourses originates from both sewage that is not collected and diffuse pollution (BRASIL, 2015).

Furthermore, a high impervious surface cover in catchments involves severe constraints on watercourse structures. Under urban conditions, watercourses are frequently confined and suffer alterations in river bed covering. Roughness expresses the flow resistance presented by the river bed covering and energy loss agents, such as vegetation and substrate composition. In this sense, a higher range of roughness values leads to greater heterogeneity; in other words, the river bed will offer more refuges to organisms (JOWETT, 2003). Consequently, the organisms will not be washed away under high velocities during larger flow events. Experimental measures of Manning's coefficient were substantially close to reference values. In the channeled site (M2), we observed the lowest value, which is similar to the theoretical value for a concrete bottom with sides of dry rubble or riprap ( 0.020 to $0.035-$ CHOW, 1959).
Concrete cover is an unstable habitat because of the lack of heterogeneous elements for major species of benthic invertebrates, such as riffles and pools, vegetation, cobble, and woody debris. From an engineering point of view, a concrete cover supplies channel stability; nevertheless, it provides unstable conditions for organisms, especially during flood events. Unstable conditions are unlikely to be suitable habitats either because food sources are not present or because the substrate does not provide a secure platform for benthic invertebrates (JOWETT, 2003). Hence, the stream habitat becomes very susceptible to disturbances due to the loss of structural complexity. The composition of FFGs indicated this trend. There were fewer taxa performing the same function in the channeled site (M2).

It is interesting to note that aquatic vegetation has mitigated the effect of channelization. The aquatic vegetation benefits invertebrate communities partly because it provides refuges against predators (GRUTTERS et al., 2015). In addition, it serves as a habitat and food resource (ROBINSON et al., 2011). High values of chlorophyll found in samples in M2 match with visual observation of sample site substrate, which was substantially composed of filamentous algae. Furthermore, dissolved oxygen did not show very low values, contrary to expectations according to urban occupation of the site that is indicated by the high values of phosphorus. This suggests that filamentous green algae (such as Oedogonium sp. and Spirogyra sp.) release oxygen to the water column during the day by photosynthesis. Robinson et al. (2011) showed that full sunlight on a stream, due to an open canopy in riparian vegetation, and nutrient load, related to urbanization, result in excessive growth of filamentous algae in channelized streams. However, the presence of this kind of algae could not be considered a long-term stability factor, since high velocities during intense precipitation cause an increase in algal sloughing (HART; FINELLI, 1999; GRAY, 2004).

Another factor associated with the effects of pollution and structural alteration is riparian condition. Table 4 highlights the lack of shredders in severely urbanized areas. Additionally, a reduced number of organisms were performing feeding functions in 
this area. Input of vegetal biomass in Atlantic Forest streams does not have a seasonal pattern; consequently, the availability of leaves and woody debris should be constant during the year. Thus, even during the short period assessed, the allochthone source does not seem to be sufficient to support an expressive number of shredders, especially in severely urbanized areas. The relation between course and fine organic matter (CPOM/ FPOM) expressed in Figure 4 reinforces this trend. The relatively low diversity of shredders also indicated an altered status. Furthermore, organisms that perform shredder functions are more sensitive to pollution (FERREIRA et al., 2012). On the other hand, gatheringcollector specimens were favored by the heterotrophic condition and the FPOM provided by domestic sewage. The high abundance of gathering collectors may be explained by the available resources and tolerance of the organisms to low dissolved oxygen and high phosphorus and nitrogen concentrations (XU et al., 2014).

It is important to bear in mind that the majority of the Chironomidae taxon was considered gathering collectors under the functional approach proposed to Cummins et al. (2005). However, Chironomidae traits, at a fine identification level, may have different categories of feeding habits: deposit-feeder, shredder, scraper, filter-feeder and predator (SERRA et al., 2017). Other studies based on gut content analysis showed that part of this taxon consists of shredder chironomids (SAITO; FONSECA-GESSNER, 2014; LEITE-ROSSI et al., 2016). According to Cummins (2016), analysis of gut content is a poor predictor of FFG assignment. The functional group designations regard to feeding mechanisms rather than food eaten because a given feeding mode, such as filtering, can result in the intake of all food categories (living or dead plant or animal material). Most stream macroinvertebrates in this regard are omnivores; however, efficiencies of assimilation may vary significantly (CUMMINS; KLUG, 1979). Thus, there are approaches focused on specific groups (SILVA-JUNIOR et al., 2017; JOVEM-AZEVÊDO et al., 2019) that provide different feeding categories from those related to an entire macroinvertebrate community.

Most samples indicated a heterotrophic metabolism, according to the attribute $\mathrm{P} / \mathrm{R}$ that represents the ratio from primary production and respiration of the community. This result seems to be consistent with one of the hypotheses of the continuum theory, in which headwater streams (orders 1 to 3) are heterotrophic (VANNOTE et al., 1980). The reference value applied to the surrogate ratio of FFGs was $\mathrm{P} / \mathrm{R}=>0.75$, representing autotrophy (MERRITT et al., 2002), whereas when $P / R=>1$, the stream ecosystem is autotrophic (VANNOTE et al., 1980). However, the zone through which streams shift from a heterotrophic to autotrophic condition is primarily dependent upon the degree of shading, i.e., it depends on the conservation status of riparian vegetation, which drives the terrestrial inputs. Therefore, urbanization could be a discontinuity that modifies expected patterns by fluvial continuum (POOLE, 2002).

Excessive abundance of predators was observed in the severely urbanized areas, notably in M2. This result was probably due to the high abundance of Hirudinea, which is a tolerant taxon (FERREIRA et al., 2012). In addition, it might be related to shallow water since similar findings have revealed the highest numbers of predators when streams formed isolated pools (STITZ et al., 2017). However, according to Merritt et al. (2002), further research should be undertaken to test the topdown control attribute. Another source of uncertainty is the habitat stability attribute. Most of the samples presented a stable substrate for limited attachment, except M1, which suggests more stability of the substrate in this area. These findings may be due to the influence of reduced velocity and high abundance of scrapers observed in this site. According to Dewson et al. (2007), the importance of riffles as retention structures of CPOM increases at lower discharge periods and CPOM retention can have strong bottom-up effects on stream ecosystems, increasing the abundance and biomass of invertebrates. Moreover, as pointed out by Juracek and Fitzpatrick (2003), classification of a stream reach as a stable stream type is potentially misleading because the reach may only appear to be stable due to a lack of recent disturbance.

The observed results were associated with the river order, the condition of riparian vegetation and the characteristics of the habitat. The habitat condition is connected with higher flow resistance of the 
substrate surface, which was represented by stream flow parameters. A river bed cover with a wide range of substrate types enhances the chance that organisms remain, increasing the taxonomic richness of FFGs. In urban areas, rain events that cause heavy disturbance of an aquatic habitat are more frequent due to changes in the water balance of catchments. Although the river bed is subject to more disturbances, if it did not provide refuges, the observed tendency is an alteration in community. Sites in urbanized areas have greater availability of labile organic matter (such as domestic sewage) and fewer refractory resources (coarse organic matter, such as leaves and branches). These results could explain the high abundance of gathering collectors and the lack of shredders in severely urbanized areas. However, the channeled site had less diversity, which is related to changes in the habitat structure. Ecosystem attributes, based on FFGs, presented conditions of riparian vegetation and river bed characteristics, providing useful data to characterize the processes of energy flux on food webs and the relation to habitat resources.

\section{Acknowledgements}

We are grateful to the Brazilian funding agency CAPES for the master's scholarship; INCT-TMCOcean (project $\mathrm{CNPq} \mathrm{n}^{-}$573.601/2008-9) for the financial support; and to the laboratories: Núcleo de Estudos do Mar (NEMAR-UFSC), Laboratório Multiusuário (Ecologia-UFSC), Laboratório de Ecologia de Águas Continentais (Limnos-UFSC) and Laboratório de Oceanografia Química (UFSC).

\section{References}

ALLAN, J. D.; CASTILLO, M. M. Stream ecology: structure and function of running waters. Dordrecht: Springer, 2007. $436 \mathrm{p}$.

ANDERSON, M. J.; GORLEY, R. N.; ClARKE, K. R. PERMANOVA+ for PRIMER: guide to Software and Statistical Methods. Plymouth: PRIMER-E, 2008.

ANDERSON, M. J. Permutational multivariate analysis of variance (PERMANOVA). Wiley StatsRef: Statistics Reference Online, 2017. p. $1-15$.

ARLETTAZ, R.; LUGON, A.; SIERRO, A.; WERNER, P.; KÉRY, M.; OGGIER, P. River bed restoration boosts habitat mosaics and the demography of two rare non-aquatic vertebrates. Biological Conservation, Boston v. 144, p. 2126-2132, 2011.
BAZINET, N. L.; GILBERT, B. M.; WALLACE,A. M.Acomparison of urbanization effects on stream benthic macroinvertebrates and water chemistry in an urban and an urbanizing basin in Southern Ontario, Canada. Water Quality Research Journal of Canada, Ontario, v. 45, n. 3, p. 327-341, 2010.

BRASIL. Diagnóstico do manejo das águas pluviais urbanas. 2015. Brasília: MCIDADES/SNSA, 2018. 190 p.

BROOKS, A. J.; HAEUSLER, T. Invertebrate responses to flow: trait-velocity relationships during low and moderate flows. Hydrobiologia, Brussels, v. 773, p. 23-34, 2016.

BROOKS, A. J.; HAEUSLER, T.; REINFELDS, I.; WILLIAMS, S. Hydraulic microhabitats and the distribution of macroinvertebrate assemblages in riffles. Freshwater Biology, London, v. 50, p. 331344, 2005.

CHOW, V. T. Open-channel hydraulics. New York: McGraw-Hill, 1959. $700 \mathrm{p}$.

CLUER, B.; THORNE, C. A stream evolution model integrating habitat and ecosystem benefits. River Research and Applications, Chichester, v. 30, p. 135-154, 2014.

CUMMINS, K. W. Combining taxonomy and function in the study of stream macroinvertebrates. Journal of Limnology, Verbania Pallanza, v. 75 , p. $235-241,2016$

CUMMINS, K. W.; KLUG, M. J. Feeding ecology of stream invertebrates. Annual Review of Ecology, Evolution, and Systematics, Palo Alto, v. 10, p. 147-172, 1979.

CUMMINS, K. W.; MERRITT, R. W.; ANDRADE, P. C. N. The use of invertebrate functional groups to characterize ecosystem attributes in selected streams and Rivers in south Brazil. Studies on Neotropical Fauna and Environment, Tübingen, v. 40, p. $69-$ 89, 2005.

DAVIS, J. A.; BARMUTA, L. A. An ecologically useful classification of mean and near-bed flows in streams and rivers. Freshwater Biology, London, v. 21, p. 271-282, 1989.

DEATH, R. G.; WINTERBOURN, M. J. Diversity patterns in stream benthic invertebrate communities: the influence of habitat stability. Ecology, New York, v. 76, p. 1446-1460, 1995.

DEWSON, Z. S.; JAMES, A. B. W.; DEATH, R. G. Stream Ecosystem functioning under reduced flow conditions. Ecological Applications, Ithaca, v. 17, p. 1797-1808, 2007.

DINGMAN, S. L. Fluvial hydraulics. New York: Oxford University Press, 2009. 559 p.

EPAGRI - EMPRESA DE PESQUISA AGROPECUÁRIA E EXTENSÃO RURAL DE SANTA CATARINA/CIRAM CENTRO DE INFORMAÇÕES DE RECURSOS AMBIENTAIS E DE HIDROMETEOROLOGIA DE SANTA CATARINA. Dados da Estação de Florianópolis (Convencional). 2014. Disponível em: <http://ciram.epagri.sc.gov.br>.

FEIO, M. J.; DOLÉDEC, S.; GRAÇA, M. A. S. Human disturbance affects the long-term spatial synchrony of freshwater invertebrate communities. Environmental Pollution, Amsterdam, v. 196, p. 300-308, 2015.

FERREIRA, W. R.; RODRIGUES, D. N.; ALVES, C. B. M.; CALLISTO, M. Biomonitoramento de longo prazo da bacia do rio das Velhas através de um índice multimétrico bentônico. 
Revista Brasileira de Recursos Hídricos, Belo Horizonte, v. 17, p. 253-259, 2012.

FROEHLICH, C. G. On-line guide: identificação de larvas de insetos aquáticos do estado de São Paulo. 2007. Disponível em: $<$ http://sites.ffclrp.usp.br/aguadoce/guiaonline>.

GRASSHOFF, K.; EHRHARDT, M.; KREMLING, K. Methods of seawater analysis. Weinheim: Verlag Chemie, 1983. 419 p.

GRAY, L. Changes in water quality and macroinvertebrate communities resulting from urban stormflows in the Provo River, Utah, USA. Hydrobiologia, Brussels, v. 518, p. 33-46, 2004.

GRUTTERS, B. M. C.; POLLUX, B. J. A.; VERBERK, W. C. E. P.; BAKKER, E. S. Native and Non-Native Plants Provide Similar Refuge to Invertebrate Prey, but Less than Artificial Plants. PLoS ONE, Cambridge, v. 10, n. 4, p. 1-18, 2015.

HART, D.; FINELLI, C. M. Physical-biological coupling in streams: the pervasive effects of flow on benthic organisms. Annual Review of Ecology, Evolution, and Systematics, Palo Alto, v. 30, p. 363$395,1999$.

HOGGART, S; FRANCIS, R.; CHADWICK, M. Macroinvertebrate richness on flood defence walls of the tidal River Thames. Urban Ecosystems, New York, v. 15, p. 327-346, 2012.

JOVEM-AZEVÊDO, D.; BEZERRA-NETO, J. F.; AZEVÊDO, E. L.; GOMES, W. I. A.; MOLOZZIE, J.; FEIO, M. J. Dipteran assemblages as functional indicators of extreme droughts. Journal of Arid Environments, Amsterdam, v. 164, p. 12-22, 2019.

JOWETT, I. G. Hydraulic constraints on habitat suitability for benthic invertebrates in gravel-bed rivers. River Research and Applications, Chichester, v. 19, p. 495-507, 2003.

JURACEK, K. E.; FITZPATRICK, F. A. Limitations and implications of stream classification. Journal of the American Water Resources Association, Maryland, v. 39, p. 659-670, 2003.

KÄIRO, K.; HALDNA, M.; TIMM, H.; VIRRO, T. The effect of channelization on the biological quality of lowland streams using macroinvertebrates as proxies. Hydrobiologia, Brussels, v. 794, p. 167-177, 2017.

LEITE-ROSSI, L. A.; SAITO, V. S.; CUNHA-SANTINO, M. B.; TRIVINHO-STRIXINO, S. How does leaf litter chemistry influence its decomposition and colonization by shredder Chironomidae (Diptera) larvae in a tropical stream? Hydrobiologia, Brussels, v. 771, p. 119-130, 2016.

LORENZEN, C. J. Determination of chlorophyll and phaeopigments: spectrophotometric equations. Limnology and Oceanography, Newfoundland, v. 12, p. 343-346, 1967.

MERRITT, R. W.; CUMMINS, K. W. An introduction to the aquatic insects of North America. 3 ed. Iowa: Kendall Hunt, 1996. 862 p.

MERRITT, R. W.; CUMMINS, K. W.; BERG, M. B.; NOVAK, J. A.; HIGGINS, M. J.; WESSELL, K. J.; LESSARD, J. L. Development and application of a macroinvertebrate functionalgroup approach in the bioassessment of remnant river oxbows in southwest. Journal of the North American Benthological Society, Lawrence, v. 21, p. 290-310, 2002.

MERRITT, R. W.; FENOGLIO, S.; CUMMINS, K. W. Promoting a functional macroinvertebrate approach in the biomonitoring of
Italian lotic systems. Journal of Limnology, Pavia, v. 76, n. 1, p. 5-8, 2017.

MESA, L. M. Hydraulic parameters and longitudinal distribution of macroinvertebrates in a subtropical Andean basin. Interciencia, Caracas, v. 35, p. 759-764, 2010.

MUGNAI, R.; NESSIMIAN, J. L.; BAPTISTA, D. F. Manual de identificação de macroinvertebrados aquáticos do estado do Rio de Janeiro. Rio de Janeiro: Technical Books, 2010. 176 p.

MULHOLLAND, P. J.; WEBSTER, J. R. Nutrient dynamics in streams and the role of J-NABS. Journal of the North American Benthological Society, Lawrence, v. 29, n. 1, p. 100-117, 2010.

NEGISHI, J. N.; INOUE, M.; NUNOKAWA, M. Effects of channelisation on stream habitat in relation to a spate and flow refugia for macroinvertebrates in northern Japan. Freshwater Biology, London, v. 47, p. 1515-1529, 2002.

NUSCH, E. A. Comparison of different methods for chlorophyll and pheopigment determination. Archiv fur Hydrobiologie, Stuttgart, v. 14, p. 14-36, 1980.

PAUL, M. J.; MEYER, J. L. Streams in the urban lansdcape. Annual Review of Ecology, Evolution, and Systematics, Palo Alto, v. 32, p. 333-365, 2001.

POOLE, G. C. Fluvial landscape ecology: addressing uniqueness within the river discontinuum. Freshwater Biology, London, v. 47, p. 641-660, 2002.

RAMÍREZ, A.; GUTIÉRREZ-FONSECA, P. E. Functional feeding groups of aquatic insect families in Latin America: a critical analysis and review of existing literature. International Journal of Tropical Biology, San José, v. 62, p. 155-167, 2014.

ROBINSON, C. T.; BLASER, S.; JOLIDON, C.; SHAMA, L. N. $\mathrm{S}$. Scales of patchiness in the response of lotic macroinvertebrates to disturbance in a regulated river. Journal of the North American Benthological Society, Lawrence, v. 30, p. 374-385, 2011.

SAITO, V. S.; FONSECA-GESSNER, A. A. Taxonomic compositions and feeding habits of Chironomidae in Cerrado streams (Southeast Brazil): impacts of land use changes. Acta Limnologica Brasiliensia, Rio Claro, v. 26, p. 35-46, 2014.

SERRA, S. R. Q.; GRAÇA, M. A. S.; DOLÉDEC, S.; FEIO, M. J. Chironomidae traits and life history strategies as indicators of anthropogenic disturbance. Environmental Monitoring and Assessment, Dordrecht, v. 189, p. 326, 2017.

SILVA-JUNIOR, E. F.; SILVA-ARAÚJO, M.; MOULTON, T. P. Distribution and abundance of freshwater decapods in an Atlantic rainforest catchment with a dammed future. Brazilian Journal of Biology, São Carlos, v. 77, n. 4, p. 820-829, 2017.

STITZ, L.; FABBRO, L.; KINNEAR, S. Response of macroinvertebrate communities to seasonal hydrologic changes in three sub-tropical Australian streams. Environmental Monitoring and Assessment, Dordrecht, v. 189, p. 189-254, 2017.

THEODOROPOULOS, C.; VOURKA, A.; STAMOU, A.; RUTSCHMANN, P.; SKOULIKIDIS, N. Response of freshwater macroinvertebrates to rainfall-induced high flows: a hydroecological approach. Ecological Indicators, Amsterdam, v. 73, p. 432-442, 2017. 
THOMSON, J. R.; TAYLOR, M. P.; BRIERLEY, G. J. Are River Styles ecologically meaningful? A test of the ecological significance of a geomorphic river characterization scheme. Aquatic Conservation: Marine and Freshwater Ecosystems, Malden, v. 14, p. 24-48, 2004.

VANNOTE, R. L.; MINSHALL, G. W.; CUMMINS, K. W.; SEDELL, J. R.; CUSHING, C. E. The river continuum concept. Canadian Journal of Fisheries and Aquatic Science, Ottawa, v. 37, p. 130-137, 1980.

VISWANATHAN, V. C.; SCHIRMER, M. Water quality deterioration as a driver for river restoration: a review of case studies from Asia, Europe and North America. Environmental Earth Sciences, Berlin, v. 74, p. 3145-3158, 2015.

WALSH, C. J.; FLETCHER, T. D.; BURNS, M. J. Urban Stormwater Runoff: A New Class of Environmental Flow Problem.

PLoS ONE, Cambridge, v. 7, p. 1-10, 2012.
WALSH, C. J.; FLETCHER, T. D.; LADSON, A. R. Stream restoration in urban catchments through redesigning stormwater systems: looking to the catchment to save the stream. Journal of the North American Benthological Society, Lawrence, v. 24, p. $690-705,2005$.

WARD, J. V. Riverine Landscapes: biodiversity patterns, disturbance regimes, and aquatic conservation. Biological Conservation, Boston, v. 83, p. 269-278, 1998.

XU, M.; WANG, Z.; DUAN, X.; PAN, B. Effects of pollution on macroinvertebrates and water quality bio-assessment. Hydrobiologia, Brussels, v. 729, p. 247-259, 2014.

YOSHIMURA, C.; TOCKNER, K.; OMURA, T.; MOOG, O. Species diversity and functional assessment of macroinvertebrate communities in Austrian rivers. Limnology, Tokyo, v. 7, p. 63-74, 2006. 